\title{
The Global Food Crisis and Guatemala: What Crisis and For Whom?
}

\author{
Alain de Janvry and Elisabeth Sadoulet ${ }^{1}$ \\ University of California at Berkeley
}

May 2009

\begin{abstract}
Food prices rose sharply on the international market between January 2005 and mid-2008, precipitating what has become known as the "global food crisis". Yet, how much of a crisis was it at the household level, and for whom was it a crisis? This paper analyzes the welfare effects of changes in prices over categories of households in Guatemala. We find three surprising results. The first is that there was no statistically significant transmission of international into domestic prices over the three and a half years that the crisis lasted. Most real staple food prices rose, but changes were modest and certainly far removed from full transmission as frequently assumed. Welfare effects were as a consequence small. The second surprising result is that, given high food dependency for farmer households, including large farmers, most of these households lost from the rise in prices, especially of course the marginal, small, and medium farmers. Only if international prices had fully transmitted would half of the large farmers have gained, with the vast majority in the other categories still losing. Allowing for price responses in both production and consumption mitigates negative effects, but still leaves a vast majority of the farmer population losing. Finally, the third surprising result is that farmer households represent as many as two-thirds of all poor households losing from rising food prices. Increasing the productivity of production for home consumption in smallholder farming can thus be an important instrument in combating the short run welfare losses of rising food prices among poor households.
\end{abstract}

\footnotetext{
1 We are indebted to Jing Cai, Luis Felipe Calva, Gianmarco Leon, Italia Piñeda, Carlos Pomareda, and Tomas Rosada for their help in developing this paper, and to the UNDP for financial support. Email addresses: adejanvry@are.berkeley.edu, sadoulet@are.berkeley.edu.
} 


\section{The global food crisis and Guatemala}

Food prices rose sharply on the international market over the period 2005 to mid-2008, creating what has been called the "global food crisis". This rapid price increase led to food riots in several countries and mobilized the international community to alleviate the plight of poor consumers. Numerous studies calculated the rise in poverty associated with higher international food prices, usually assuming perfect food markets with full transmission of prices from world to domestic markets and without allowing for quantity adjustments in production and consumption. Yet, it is quite possible that the assumptions made - full transmission and lack of responses in production and consumption even when calculations were made after prices had been rising for more than two years - led to over-estimating the magnitude of the poverty impacts in many countries. Clearly, the global food crisis had complex and heterogeneous effects. Price transmission was quite different across countries and commodities. Different categories of households were differentially affected according to their net positions on food markets, as sellers or buyers, and according to their poverty status. And there was some response to prices, both by increases in production and substitutions in consumption, mitigating negative impacts. Now that the excitement of the crisis has waned, with prices declining sharply after mid-2008, more careful assessments need to be made as to what really happened for specific countries and specific categories of households, particularly as the return of high food prices is quite likely to occur. We do this for Guatemala, a poor country highly dependent on imports for key staple foods and with a high rate of urbanization and landlessness that should, a-priori, have been quite negatively affected by the crisis. And, yet, as we will see, results show important surprises, implying that the crisis was not as large as expected and that social categories most negatively affected were largely not the urban poor, as per conventional wisdom.

In this paper, we carefully analyze the transmission from international to domestic prices. This is different from studies that have analyzed the welfare effects of higher food prices on 
poverty rates by simply assuming full price transmission, as for example in Ivanic and Martin (2008) for the two-year period 2005-2007. Results from this study predicted that poverty across all low-income countries would increase by 105 million people, becoming one of the most frequently cited result to describe the welfare effects of the global food crisis (BBC News, 2008). Reality may be different. Transmission can be quite incomplete and heterogeneous across commodities, as shown for example by Daviron et al. (2008) for West Africa. Using data for 76 countries, De Hoyos and Medvedev (2008) find that domestic relative food prices rose by only $18 \%$ of the rise in international relative food prices over the three year period $2005-07$. In this paper, we also go beyond calculation of the impact of changing prices on poverty rates as done in the studies conducted at the World Bank (Ivanic and Martin, 2008; Busjeet, Demombynes, and Sobrado, 2008) and the Inter-American Development Bank (Robles, Cuesta, Duryea, Enamorado, Gonzales, and Rodríguez, 2008). Designing policy interventions to address the welfare costs of rising food prices on the poor requires measuring the incidence of gains and losses across different types of households. We do this by disaggregating households into categories based on sector of residence and access to land in order to contrast their net positions on food markets. We simulate the impact of observed price changes, as well as of what the crisis could have been had there been full transmission from international to domestic prices. We do this in both the short run without price responses, and in the medium run with adjustments in both consumption and production.

We address these issues for Guatemala, a country with a still extensive rural population (52\%), a high rural poverty rate (71\% vs. $30 \%$ urban), a large share of rural households engaged in farming (70\%), a large share of the total number of poor engaged in farming (56\%), and a very large share of the rural poor engaged in farming (72\%) (World Bank, 2008). These figures suggest that focusing on the urban poor ( $28 \%$ of the total number of poor) would not be sufficient. Special attention needs to be given to the rural poor and among them to those with access to land (67\% of the total number of poor). 
We first proceed to characterize the magnitude of the domestic price shocks at the consumer and producer levels. We use time series techniques to estimate the extent of international price transmission. A first surprise reported in this paper is that price transmission has been muted and not statistically significant. Many domestic food prices have increased in real terms, but changes cannot be shown to have been due to the international price shock over the three year period during which international market prices rose sharply. Most of the increase was late in the crisis period, much smaller than the rise in international prices, and some prices actually declined in real terms. This in spite of the fact that Guatemala has fallen into increasing food dependency for staple foods and that several of the foods importantly consumed by the poor are very marginally produced in the country, in principle exposing the population to a price shock in consumption. We then create a typology of rural and urban households that stresses access to land. We characterize the production and consumption structure of these different types of households. For a given vector of price shocks reflecting what happened in Guatemala over the last two and a half years, this allows to trace the absolute and percentage changes in welfare for each household category, as well as the share of losers in each. A second surprise reported in this paper is that most households lost from changing prices, including most medium and large farmers because they only partially produce what they consume. This holds true even when allowing for price response in production and consumption, a counter-intuitive result. A third surprise is that, among the poor who lost from rising prices, either as occurred on the domestic market or if there had been full price transmission from international to domestic prices, some two-thirds are landed households. This has important policy implications, suggesting how rising productivity in using land to produce for home consumption can be an important element of social protection in a context of rising food prices. While little attention has been given by policy makers to the role of "farm-finance social welfare" (Owen, 1966) in the context of price or income shocks, production for home consumption in countries where poverty is still importantly linked to access to land needs to be part of the array of instruments in facing up to a food crisis. 


\section{Global food crisis, price transmission, and domestic price increases}

As can be seen in Figure 1, food prices increased sharply on the international market over the period January 2006 to July 2008. As reported in Table 1, the average annual growth rates in international prices over that period were $47 \%$ for rice, $44 \%$ for maize, $43 \%$ for wheat, and $54 \%$ for soybeans. Domestic prices also increased in real terms. Compared to an annual growth rate in the CPI of $8.4 \%$, nominal consumer prices increased by $20 \%$ for rice, $14 \%$ for maize, $27 \%$ for bread, $24 \%$ for edible oils, and $6 \%$ for beans. Using wholesale prices measured at the central market of Guatemala city to represent producer prices, nominal producer price increased by $29 \%$ for rice, $14 \%$ for maize, and $11 \%$ for beans.

Guatemala is a country that is a net exporter of agricultural goods and of food, but the exportable surplus of both food and agriculture has been declining over the last 25 years (Figure 2). Import dependency in staple foods has been rising rapidly as the country shifted successfully to the production of non-traditional exports, focusing on comparative advantage in trade and neglecting like other countries in the region concerns with food security policy (Pomareda, 2008). In 2003-05, the import dependency ratio, defined as imports over consumption (equal to production - exports + imports) was $68 \%$ for rice, $35 \%$ for maize, $98 \%$ for wheat, $18 \%$ for soybeans, and $9 \%$ for beans. The country is thus quite food dependent in rice and wheat, but not in maize and beans. The shares of the four major basic grains in consumption are $71 \%$ for maize, $20 \%$ for wheat, $5 \%$ for rice, and $4 \%$ for beans (Table 1 ). The major welfare shocks coming from rising domestic prices should thus be due to maize (high share in consumption) and wheat (high import dependency).

Figure 1 shows that there has been very partial transmissions from international prices to wholesale prices across commodities. An Inter-American Development Bank (2008) study of the impact of the global food crisis on Guatemala similarly found little price transmission, except 
possibly for rice and in 2008 for maize. We need turn to econometrics to assess how much the observed changes in domestic prices may be due to international price transmission.

\section{Econometric analysis of price transmission}

In order to estimate the pass-through coefficients of international into domestic food prices, we follow previous work (Isard, 1977; Richardson, 1978; Mundlak and Larson, 1992; Baffes and Gardner, 2003) and estimate the following relationship:

$$
p_{t}^{d}=\mu+\beta p_{t}{ }^{w}+\varepsilon_{t}
$$

where $p_{t}{ }^{d}$ and $p_{t}{ }^{w}$ are respectively the domestic and international prices of a given commodity at time $t$ and $\varepsilon_{t}$ is white noise. $\beta$ is the pass-through parameter of interest.

In order to verify stationarity, we estimate equation (1) for every product and test for the presence of a unit root using the standard time series tests. When we are unable to reject the null hypothesis of the presence of a unit root, we proceed to difference the series and estimate equation (1) using differenced data. We then estimate:

$$
\Delta p_{t}^{d}=\alpha+\gamma \Delta p_{t}^{w}+v_{t}
$$

In this case, we also proceed to test for the presence of a unit root in the error term after the estimation of equation (2). Autocorrelation is tested using the Durbin-Watson statistic. Whenever we are unable to reject the no serial correlation hypothesis, we use the Prais-Winston estimation, which is a Generalized Least Squares estimator that takes into account the correlation coefficient between the error terms of periods $t$ and $t-1$ to account for the autoregressive structure of the data.

It might well be the case that the transmission from international to domestic prices is not immediate, and has lags due to transportation costs, storage, etc. This possibility is considered by estimating equation (2) including lagged values of the relevant international price. In order to 
determine the optimal number of lags to be used in this estimation, we use the Akaike Information Criterion (AIC) (Akaike, 1974), which is a measure of the goodness of fit of a statistical model used to discern between models. The preferred model will be the one which has the lowest AIC.

The domestic price data used for the analysis were obtained from the local statistical office and central bank, while the international commodity prices were obtained from the International Finance Statistics of the IMF. In order to have similar scales on both sides of the estimated equation, and to separate the effect of local price inflation, we deflate local prices using the CPI, while the international prices are transformed in local currency and deflated.

\section{Results from transmission analysis}

We use monthly data for the period January 2005 to August 2008 over which prices rose on the international market. Data are for maize at the consumer (tortilla) and producer levels, rice at the consumer and producer levels, wheat at the consumer level (bread), and soybeans at the producer level. This econometric estimation was conducted for no lag, one lag, and two lags. Using the Akaike criterion to chose the best model, the zero lag specification fits best for all cases, except soybeans where the two lags option gives the best fit. Results indicate that there was no significant transmission, except for the price of rice at the producer level where transmission is in fact negative. ${ }^{2}$

Figure 1 shows that there was some transmission but that it was very short run and not part of a sustained process over the period. The price changes we study cannot consequently be said to be due to sustained international market price transmission over the two-and-a-half year period. Low price transmission is thus the first surprising result of this paper that was motivated by the

\footnotetext{
${ }^{2}$ Results are not reported in a table as they are essentially non-results.
} 
global food crisis. Other studies have noted the country and commodity specificity of price transmission, with low transmission not an unusual phenomenon (Abbott, 2009).

Price transmission for an imported food can be expected to be greater if there is high import dependency, markets are well integrated with low transactions costs, processing costs are a low share of the final product, there are few close substitutes in consumption among domestic alternatives (proxied by a high share in consumption), there are low trade policy interventions such as import tariffs, there are no defensive policy actions (such as lowering tariffs and raising export taxes), and there is no monopoly power in importing and processing (Timmer, 2008; Abbott, 2009). These conditions help understand the observed low and differential transmissions across cereals in Guatemala (Pomareda, 2008). In the case of wheat (Table 1), there is high import dependency (98\%) and high monopoly power in imports contributing to pass-through, but wheat has a low share in basic grains consumption (20\%), processing costs that are a high share of the final product, and zero import tariff. As a result, price transmission has been relatively high $(62 \%)$, though far from perfect. For rice, there is fairly high import dependency $(68 \%)$ and a quasi monopoly in imports by a few mills contributing to pass-through, but price transmission is muted by high transactions and transformation costs on imported paddy (with a $66 \%$ conversion factor of paddy into white rice), a very low share in basic grains consumption (5\%), a $24 \%$ import tariff, and competition with contraband rice coming from the United States through Mexico that does not pay import tariff and value added tax. Price transmission has consequently been muted (42\%). Finally, for maize, the share in grain consumption is very high $(71 \%)$ and there are low transactions costs contributing to pass-through, but import dependency is low (35\% for yellow corn and zero for white corn) and transactions costs on domestic markets are high. As a consequence, there has been low price transmission (32\%). 


\section{Simulation of changes in domestic prices}

In what follows we will simulate the welfare effect of the observed relative changes in the prices of rice, maize, wheat, beans, soybeans, and edible oil for producers and consumers. Relative price increases are obtained by netting out the overall CPI increase. This is equivalent to assuming that all other prices and incomes change with the overall CPI. The purpose of this method is to neutralize the effects of any other price changes not related to the food crisis. We use the annual growth rates reported in Table 1, i.e.:

- On the consumer side, relative price increases of $10.5 \%$ for rice, $5.3 \%$ for maize, $17 \%$ for bread, and $13.9 \%$ for edible oil, and a relative decline of $2.5 \%$ for beans.

- On the producer side, relative price increases of $18.6 \%$ for rice, $5.6 \%$ for maize, and $2.1 \%$ for beans.

In a similar study for Guatemala, Sobrado, Demombynes, and Rubiano (2009) analyze the impact of the observed changes in real consumer and producer prices for all food items as well as in real wages induced by these price changes using wage predictions in the general equilibrium model GTAP (Global Trade Analysis Project) over the period May 2007 to October 2008. Their study differs from ours in that their social disaggregation if for rural/urban, poor/non-poor, and by income quintiles as opposed to a household typology that stresses net-seller net-buyer positions on markets in relation to farm size. With the disaggregation they use, their results indicate that the urban poor are the ones whose consumption fell the most, in part because they predict rising rural wages that help compensate the rural poor for rising food prices. Our results stress instead that most poor losers from rising food prices are rural and farmer households $(68 \%)$, putting emphasis on the need to address rural and landed poverty. 


\section{Typology of households}

Table 2 reports on a classification of Guatemala households into seven categories using the 2006 Household Survey ENCOVI (World Bank, 2008). The ENCOVI surveyed almost 14,000 households and includes sufficiently developed income and agricultural modules to allow for the analysis of the effect of food price increases on welfare.

This typology shows that $52 \%$ of the population is in rural households, and $46 \%$ of the population is in households with access to land. There are both farmers in urban areas $(9 \%$ of the population) and non-farmers in rural areas $(15.5 \%$ of the population). Poverty rates are highest among marginal, small, and medium farmers, reaching respectively $76 \%, 81 \%$, and $80 \%$ when using the general poverty line in 2006 equal to Q6,574 (US\$865). These three categories account for half (51\%) of the poor. All landed households, rural and urban, together account for $66.6 \%$ of the total number of poor. The remaining non-landed poor are $17.6 \%$ urban and $15.8 \%$ rural. Landed poverty is thus an important phenomenon in Guatemala in spite of the $48 \%$ rate of urbanization of the population. Since, as we will see, a large majority of these landed poor are negatively affected by the food crisis, they should be a major social category of concern in targeting policy responses to the food crisis.

The distributions of consumption per capita for each of the seven household categories are reported in Figure 3. The only social category with its modal consumption to the right of the poverty line (with a poverty rate of $23 \%$ ) is the urban non-farmers. The rural non-farmers have their mode consumption at about the poverty line (with a poverty rate of 52\%). All farmer categories have their modal consumptions substantially to the left of the poverty line, indicating that a large majority of their constituencies are in poverty.

Analyzing the welfare effect of the food price changes requires information on the consumption and production of the crops and commodities of interest (maize, wheat, beans, rice, soybeans, and edible oil) for each household, as well as on the share of consumption that is 
purchased and of production that is sold. This information is available in the ENCOVI 2006. On the production side, the annual production of these crops is allocated between sales and own consumption as food or feed, reporting quantities and values. On the consumption side, the survey records both "normal" monthly purchased and non-purchased consumption (from gifts, own production, etc.), and the specific information over the last 15 days. We choose to use the "normal" monthly values to build the annual purchase and consumption aggregates. The most directly transformed products (flour, bread, and tortillas) are included in the corresponding cereals, but not the more processed goods such as corn flakes and pastas. Consumption, purchases, production, and sales are recorded in values. We use geographical deflators to normalize all monetary values to standard national prices. The total consumption aggregate was made available by the team that first processed the ENCOVI survey; it is also recorded in standard national prices.

As seen in Table 3, staple foods represent an important share of consumption for all households, but particularly for farmers where they reach $20 \%$ of total expenditures for the small and medium categories. Maize and wheat have the highest shares in consumption. The production of staple foods is dominated by maize and beans. There is no production of wheat and only minimal production of rice by the larger farmers. And no group on average produces more than it consumes, suggesting a large dependence on purchased food, even among farmers. The self-sufficiency ratio is the share of consumption that the households does not purchase. It mainly proceeds from own production, but some of it also comes from wages paid in kind or from gifts. For that reason even non-agricultural households have a certain level of "self-sufficiency". Another indicator of the link between production and home consumption is the ratio of production that is domestically used for food or feed rather than sold.

For maize, on average households have direct access to $59.6 \%$ of what they consume, ranging from $61 \%$ for marginal farmers to $94 \%$ for large farmer. For beans, the self-sufficiency 
ratio is on average $25 \%$, ranging from as low as $14 \%$ for marginal farmers to $68 \%$ for large farmers. Seen from the angle of production, however, marginal farmers consume almost all their production ( $94 \%$ for maize and $91 \%$ for beans), while large farmers consume around a third of the maize $(38 \%)$ and beans $(33 \%)$ they produce.

We thus conclude that Guatemala has the peculiarity that all farmer categories are net buyers of staple foods, even the "large" farmer category which on average farms only 10.6 ha of land. All farmers will consequently be negatively affected by a rise in the price of staple foods, most particularly the marginal farmers. At the same time, all farmer categories importantly depend on production of cereals for home consumption, with the medium (76\%) and large (74\%) farmers achieving the highest levels of self-sufficiency. Even for marginal farmers, production of cereals for home consumption (41\%) is an important source of supply. Rising productivity in production for home consumption can thus be an important instrument to meet the food deficits of all farmer categories.

\section{Simulating the effects of food price changes on poverty}

Evaluating the effect of the price changes on poverty is done by adjusting the poverty line to reflect the changing cost of the basic basket of goods that defines the poverty line. This is what we first do, ignoring the possible gain/loss in agricultural income. We then also add the simulated effect on agricultural income in calculating the new poverty line.

The adjustment to the poverty line should be equal to the increase in total expenditures that would be necessary to maintain the marginal poor at the same level of welfare after the price increase (de Janvry and Sadoulet, 2008). A first order linear approximation gives a value equal to the share of food consumption times the increase in its relative price. Empirically, we consider households with consumption per capita close to the poverty line (within the range of $5 \%$ above and below the poverty line) to represent the marginal poor. We then compute for these 
households the change in the cost of their observed consumption basket due to the price changes, as:

$$
d z_{h}=\sum_{i} E_{i h} \frac{d p_{i}}{p_{i}}
$$

where $E_{i h}$ is the expenditure per capita of household $h$ on commodity $i, d p_{i} / p_{i}$ is the proportional change in the price of commodity $i$, and $d z_{h}$ the change in total expenditures per capita for household $h$. Note that in these calculations, "expenditures" $E$ must include the value of all consumption, including consumption of own-produced goods or received in kind, and cost increases are computed using consumer price changes which assumes that all households purchase their consumption. The necessary adjustment to the poverty line is $d \bar{z}$, the average change in cost of the consumption basket for households close to the poverty line.

Results are reported in Table 4. They show that these marginally poor households spend $14.9 \%$ of their budget on staple foods (maize, wheat, rice, beans, and oil), with maize and wheat accounting for most of this consumption. So they are affected by the increase in wheat and maize prices. On average the price of their staple foods consumption increases by $8.5 \%$, which would lead to an increase in their per capita expenditures of 82.9 Qz. Hence this is the amount by which the poverty line needs to be adjusted. It corresponds to an increase of $1.3 \%$ in the poverty line.

If, instead of the change in domestic prices, we consider the change in international prices as though there had been full price transmission, the price of staple consumption for the marginal poor would have increased by $40.1 \%$, and the increase in per capita expenditure by 394.8 Qz. It corresponds to a significant increase of $6 \%$ in the poverty line. The change in per capita agricultural income is positive, equal to $1.1 \%$ of its base value.

We now examine these cost of living and agricultural income effects on poverty on all households, by sector of residence and farm size. Ignoring first the agricultural income effect, 
new poverty rates are simply calculated by comparing the expenditures per capita with the new poverty line, set at 6568.8 Qz rather than 6573.9 Qz. Results are reported in Table 5. They show that the poverty rate increases from 51.0 to $51.7 \%$. This small increase in the poverty rate as domestic food prices changed in the context of the global food crisis can thus come as a surprise. As seen above, they are due to the small transmission from international prices and the modest domestic changes in real prices, as well as the households' diversified consumption and production structures with low weights for staple foods. Had there been full international price transmission, the poverty rate would have increased to $54.1 \%$, an important 3.1 percentage points increase.

To take into account the first-order effect that the changes in agricultural prices have on farmers' incomes, we compute for each household an income effect as:

$$
d y_{h}=\sum_{i} P_{i h} \frac{d p_{i}^{p}}{p_{i}^{p}}
$$

where $P_{i h}$ is the value of production of staple $i$ by household $h$, and $d p_{i}^{p} / p_{i}^{p}$ the change in the producer price of commodity $i$. The per capita change in income is added to the initial expenditure per capita, and the total compared to the new poverty line to establish the poverty status of the household. A household is now poor if:

$$
E_{h}+\frac{d y_{h}}{\text { hhsize }}<\text { povline }+\overline{d z}
$$

where $E_{h}$ is the household baseline expenditures per capita, hhsize household size, and $\overline{d z}$ the adjustment to the poverty line computed above. Note that income effects are computed using the total value of production (and not only sales) and producer price changes. For the change in domestic prices, the impact on the poverty rate is not visible. With full price transmission, as per capita agricultural incomes rise, the poverty rate would have risen to only $53.6 \%$ instead of $54.1 \%$. Taking into account the price effect thus reduces the rise in poverty from 3.1 to 2.6 percentage 
points. The decline in poverty rate due to the income effect of rising prices is most notable for the large farmers, whose poverty rate decreases from $72.4 \%$ without income effect to $70.1 \%$ with income effect.

\section{Simulating the short-term welfare effects of food price changes}

\subsection{Impact of changes in domestic staple food prices on farmer households}

In this section, we simulate the household specific net welfare gains from domestic price changes. This requires information on households' purchases and sales of food products, rather than consumption and production. The upper panels of Tables 6 and 7 give the purchases of five main staples - rice, wheat, maize, beans, and edible oils - and the sales of three main crops - rice, beans, and maize - by household category. They also give the shares of households in each category that are net buyers of these products. Households are classified by sector of residence and farm size in Table 6 and by sector of residence and poverty status in Table 7.

The first order effect of an increase in a price for a household is proportional to the net sale/purchase of the product (de Janvry and Sadoulet, 2008; see also Chen and Ravallion, 2003). It can be written as:

$$
d W_{h}=\sum_{i} S_{i} \frac{d p_{i}^{q}}{p_{i}^{q}}-\sum_{i} P_{i} \frac{d p_{i}}{p_{i}}
$$

where $S_{i}$ is sale and $P_{i}$ purchase of good $i$, and $p_{i}^{q}$ and $p_{i}$ are producer (sale) and consumer (purchase) prices. We simulate the effect of the domestic cereal and edible oil price increases relative to the overall CPI as reported in Table 1.

We observe that although wheat consumption was about half of maize consumption (Table 3), it dominates maize in purchases across household categories except the marginal farmers and rural non-farmers. This is because there is basically no wheat production in Guatemala. All 
household categories will consequently be vulnerable and lose from the large (17\%) increase in the relative price of bread.

There are net buyer and net seller households within each farmer category. Given the structure of production and consumption in Guatemala, with a high rate of food dependency, net food buyers dominate net sellers across all farm categories, even that of large farmers. Net buyers are least frequent among large farmers for maize $(15.2 \%)$ and beans $(35.1 \%)$, and medium farmers $(27.6 \%$ and $43.6 \%$, respectively) (Table 6). Most marginal farmers are highly dependent on purchases for their consumption, reaching $79.9 \%$ for maize and $84.8 \%$ for beans.

The impact of changes in the domestic prices of staple foods on categories of households is presented in the lower panels of Tables 6 and 7. The most remarkable result is that there are few gainers from the price changes, with medium and large farmers gaining from higher maize prices (Table 6). Considering all price changes, only $42 \%$ of the larger farmers gain (58.3\% net losers) and $20 \%$ of the medium farmers. Net losers reach $98.7 \%$ among marginal farmers and $95.3 \%$ among small farmers. It would thus be totally wrong to believe that these smallholders could have benefited from the observed price changes. They lose nearly as frequently as urban non-farmers (98.5\%) and rural non-farmers $(98.7 \%)$ do.

Contrasting poor and non-poor households in the rural and urban sectors in Table 7 shows that there are few differences. The vast majority (95\%) of all four categories lose from the domestic price changes, both urban and rural, with an expected somewhat larger incidence of losers among urban households.

\subsection{Impact of changes in international staple food prices on farmer households}

To see what would have been the magnitude and distribution of gains and losses had there been full price transmission from international into domestic prices, we simulate the welfare effects due to changes in international prices of $47.2 \%$ for rice, $44.1 \%$ for maize, $42.9 \%$ for wheat, and $54.4 \%$ for soybean/edible oil for both producers and consumers. Because all prices 
rise, and changes are large, there are more consistent welfare impacts (Table 8). In this case, large farmers gain overall (a gain equal to $2.4 \%$ of their total expenditures), with gains coming from their net sales of maize (3.9\%). There is a larger share of gainers among large and medium farmers, reaching 53.5\% among the first and $28.8 \%$ among the second. Again, marginal and small farmers are mainly losers, with $98.2 \%$ and $91.5 \%$ of them losing, respectively.

Contrasting poor and non-poor households shows that the urban households are more exposed to rising prices, but that there are no major differences by poverty status (Table 9). Among the urban, $95.9 \%$ of the poor and $97.7 \%$ of the non-poor lose; among the rural, $88.6 \%$ of the poor and $89.3 \%$ of the non-poor lose.

A second surprise from the results obtained in this paper is thus that a rise in prices produces many losers, even among the farmer population. The vast majority of marginal, small, and medium farmers lose in spite of being producers. Only among the larger farmers representing less that $4 \%$ of the population do we find a little over half of the households gaining. Clearly, given the high level of food dependency across all household categories, a rise in food prices due to international transmission would have had a high short run welfare cost.

\section{Simulating the medium-term welfare effects of the food price changes, with supply and demand responses}

In the medium term, a more nuanced welfare effect may be observed when accounting for the demand and supply responses to price changes. In particular, one can expect consumers to adjust their consumption to the new price structure by reducing consumption of commodities whose prices have increased and substituting for lower price commodities. And symmetrically, producers can be expected to shift their production toward more of the high price commodities, either by intensifying production or reducing the production of other crops. So losses are lessened and gains are fostered. 
Changes in production respond to changes in the opportunity cost of production. Following the standard household behavior model, the opportunity cost of production is the sale price for producers that sell, while it is the purchase price for those that only produce for home consumption, as increased production substitutes for purchases. Self-sufficient households that neither buy nor sell are not affected by the price changes. In Guatemala 13-16\% of households are neither buyer nor seller of each of the staple goods -- rice, maize, and beans --, and a small percentage of households (1-3\%) both buy and sell each of them. For the latter, purchases and sales may be of slightly different quality or at different times of the year, and hence we need to consider both.

In a situation where several prices change at the same time, one should consider not only the direct price response of a crop supply to its own price, but also the cross-price elasticities with respect to the other crop prices that are substitutes in production. And if the set of crops that face a change in price is large enough in total agricultural production, one would also need to select a set of direct and cross price elasticities that satisfy a meaningful aggregate supply response. We will ignore these issues for now, since cereal production is only a small share of the agricultural portfolio in Guatemala. And lacking an estimate of those direct supply elasticities, we conduct the analysis with an assumed value of 0.3 for rice, maize, and beans.

Similarly on the demand side, we ignore cross price elasticities, and assume direct price elasticities equal to -0.3 for rice, maize, wheat products, and beans.

Hence the change in production is:

$$
d Q_{i}=Q_{i} \varepsilon_{i}^{S} \frac{d p_{i}^{S}}{p_{i}^{S}} \text { for sellers and } \quad d Q_{i}=Q_{i} \varepsilon_{i}^{S} \frac{d p_{i}^{b}}{p_{i}^{b}} \text { for buyers, }
$$


where $Q_{i}$ and $\varepsilon_{i}^{S}$ are production and the supply elasticity of commodity $i$, respectively, and $p_{i}^{S}$ and $p_{i}^{b}$ the sales and purchase prices of commodity $i$. Symmetrically the change in consumption is:

$$
d C_{i}=C_{i} \varepsilon_{i}^{C} \frac{d p_{i}^{b}}{p_{i}^{b}} \text { for buyers and } \quad d C_{i}=C_{i} \varepsilon_{i}^{C} \frac{d p_{i}^{S}}{p_{i}^{S}} \text { for sellers, }
$$

where $C_{i}$ and $\varepsilon_{i}^{C}$ are consumption and the demand elasticity, respectively.

Assuming that the marginal utility of income remains constant, the welfare effect can be measured by: ${ }^{3}$

$$
\begin{aligned}
d W & =\sum_{i} p_{i} Q_{i}\left(1+\frac{1}{2} \varepsilon_{i}^{q} d \ln p_{i}\right) d \ln p_{i}-\sum_{i} p_{i} C_{i}\left(1+\frac{1}{2} \varepsilon_{i}^{c} d \ln p_{i}\right) d \ln p_{i} \\
& =\sum_{i}\left(1+\frac{1}{2} \frac{d Q_{i}-d C_{i}}{Q_{i}-C_{i}}\right)\left(Q_{i}-C_{i}\right) d p_{i}
\end{aligned}
$$

where the relevant price $p_{i}$ is the sale price for net sellers and the purchase price for net buyers.

Results from these simulations for changes in international prices are reported in Table 10 for households classified by sector of residence and farm size. All categories gain or mitigate losses from adapting their consumption and production to price changes. Gains in welfare due to price responses compared to what they were without response in Table 8 are largest for the large, medium, and small farmers. With price responses, the percentage of large farmers losing from the price change falls from $46.5 \%$ to $38 \%$, and that of medium farmers from $71.2 \%$ to $58.4 \%$. But the second surprise encountered in this paper remains effective: even with price responses, most farmer households lose from a rise in prices, especially among marginal farmers (95.3\%), small farmers $(80.7 \%)$, and medium farmers $(58.4 \%)$.

\footnotetext{
3 See de Janvry and Sadoulet (2008).
} 
Responses by poverty status are given in Table 11 . Here it is mainly the rural poor who gain from adjusting production and consumption. The share of losers among them falls from $88.6 \%$ without price response to $80.4 \%$ with price response. Notable, however, is that the percentage of losers in the whole population remains high even with price responses, with an overall share of losers equal to $89 \%$ instead of $92.8 \%$ without adjustments to higher prices.

\section{Importance of production for home consumption among poor losers}

Given the structure of food production, consumption, trade dependence, and price transmission in Guatemala, most households lose from the effects of a food crisis. It is only among large farmers that short-term losers fall to $58.3 \%$ with the observed domestic price changes and $46.5 \%$ with international price transmission. We are interested in characterizing here how important is the farmer population among the poor that are losing from the price changes.

In Guatemala, farmers represent $45.6 \%$ of the population and $66.6 \%$ of the poor (Table 12). Because most of the poor farmers are net buyers, we find that $64.7 \%$ of the poor who lose are farmers with domestic price changes, and $63.6 \%$ with the international price changes. This the third surprise of this paper. We find that landed households are very important among poor losing households, representing about two-thirds of all losers. Improving production for home consumption, and eventually for sale of a marketed surplus of food, among these households is an important policy instrument that deserves greater attention than it has received.

\section{Conclusions}

Results in this paper yielded three surprises when analyzing the impact of the "global food crisis" on Guatemala: low transmission of international into domestic prices, the vast majority of farmer households losing from a rise in food prices, and the majority of poor losers from rising food prices found among landed households. This implies that blanket analyses of the poverty impacts of the food crises that do not take into account the actual degree of price transmission (assuming instead full transmission) and that do not disaggregate farm households in terms of 
their net positions on food markets can reach erroneous conclusions. A more detailed analysis reveals in particular the importance of landed households, who represent the majority of the country's poor, among poor losers from rising prices. It suggests the importance of boosting their capacity to produce for home consumption as an effective - and yet much neglected - policy instrument in reducing the welfare costs of rising food prices. The government of Guatemala has planned its short run responses to rising food prices on social assistance (expansion of coverage of the Mi Familia Progresa program, particularly in rural areas) and boosting production in smallholder farming through the distribution of improved seeds, fertilizer subsidies, and land rental through the Fondo Nacional de Tierras (IDB, 2008; Pomareda, 2008). Implementation of these policies has not been evaluated, but casual observations suggest only partial implementation, weak targeting of fertilizer subsidies on smallholder farmers, and lack of complementary technical assistance to help make good use of the additional inputs. Yet, the results presented here, and the surprises encountered in the analysis, give strong support to pursuing these two approaches to reducing vulnerability of the poor to rising food prices. 


\section{References}

Abbott, Philip. 2009. "Development Dimensions of High Food Prices." Department of Agricultural Economics, Purdue University.

Akaike, Hirotugu. 1974. "A new look at the statistical model identification." IEEE Transactions on Automatic Control 19(6): 716-723.

Baffes, John, and Bruce Gardner. 2003. "The Transmission of World Commodity Prices to Domestic Markets Under Policy Reforms in Developing Countries." Policy Reform 6(3): 159-180.

BBC News. 2008. "World Bank tackles food emergency.” April 14. http://news.bbc.co.uk/2/hi/business/7344892.stm

Busjeet, Gita, Gabriel Demombynes, and Carlos Sobrado. 2008. "Food Prices and the Poor in Latin America." The World Bank, LAC Poverty and Gender Group.

Chen, Shaohua, and Martin Ravallion. 2003. Household Welfare Impacts of China's Accession to the World Trade Organization. The World Bank, Development Research Group, WPS3040.

Daviron, Benoît, et al. 2008. "La transmission de la hausse des prix internationaux des produits agricoles dans les pays Africains." CIRAD-FARM.

De Hoyos, Rafael, and Denis Medvedev. 2008. "Poverty Effects of Higher Food Prices: A Global Perspective." Washington D.C.: The World Bank.

de Janvry, Alain, and Elisabeth Sadoulet. 2008. "Methodological Note: Estimating the Effects of the Food Price Surge on the Welfare of the Poor." University of California at Berkeley, available at http://are.berkeley.edu/ sadoulet/.

Inter-American Development Bank. 2008. "Impacto del aumento de los precios de los alimentos in Guatemala." Washington D.C.

Isard, P. 1977. "How far can we push the "law of one price'?" American Economic Review 67: 942-948.

Ivanic, Maros, and Will Martin. 2008. "Implications of Higher Global Food Prices for Poverty in Low-Income Countries." The World Bank, Development Research Group Trade Team, WPS4594.

Mundlak, Yair, and Donald Larson. 1992. "On the transmission of world agricultural prices." The World Bank Economic Review 6: 399-422.

Owen, Wyn. 1966. "The Double Developmental Squeeze on Agriculture.” American Economic Review 56(1): 43-70. 
Pomareda, Carlos. 2008. "Medidas de Política Agrícola en la Estrategia Agroalimentaria en Centroamérica: Analísis y Recomendaciones." Servicios Internacionales para el Desarrollo Empresarial s.a. San José, Costa Rica.

Richardson, J. D. 1978. "Some empirical evidence on commodity arbitrage and the law of one price." Journal of International Economics 8: 341-351.

Robles, Marcos, Jose Cuesta, Suzanne Duryea, Ted Enamorado, Alberto Gonzales, and Victoria Rodríguez. 2008. Rising Food Prices and Poverty in Latin America: Effects of the 2006-2008 Price Surge. Washington D.C.: Inter-American Development Bank.

Sobrado, Carlos, Gabriel Demombynes, and Eliana Rubiano. 2009. "El impacto del incremento en el precio de los alimentos sobre la pobreza en Guatemala." Washington D.C.: The World Bank.

Timmer, Peter. 2008. Causes of High Food Prices. Asian Development Bank Economic Working Papers Series No. 128. Manila.

World Bank. 2008. Guatemala Poverty Assessment: Good Performance at Low Levels. Washington D.C. 
Figure 1. Evolution of international and nominal domestic food prices in Guatemala, January 2005 to February 2009 and period of analysis January 2006 to July 2008
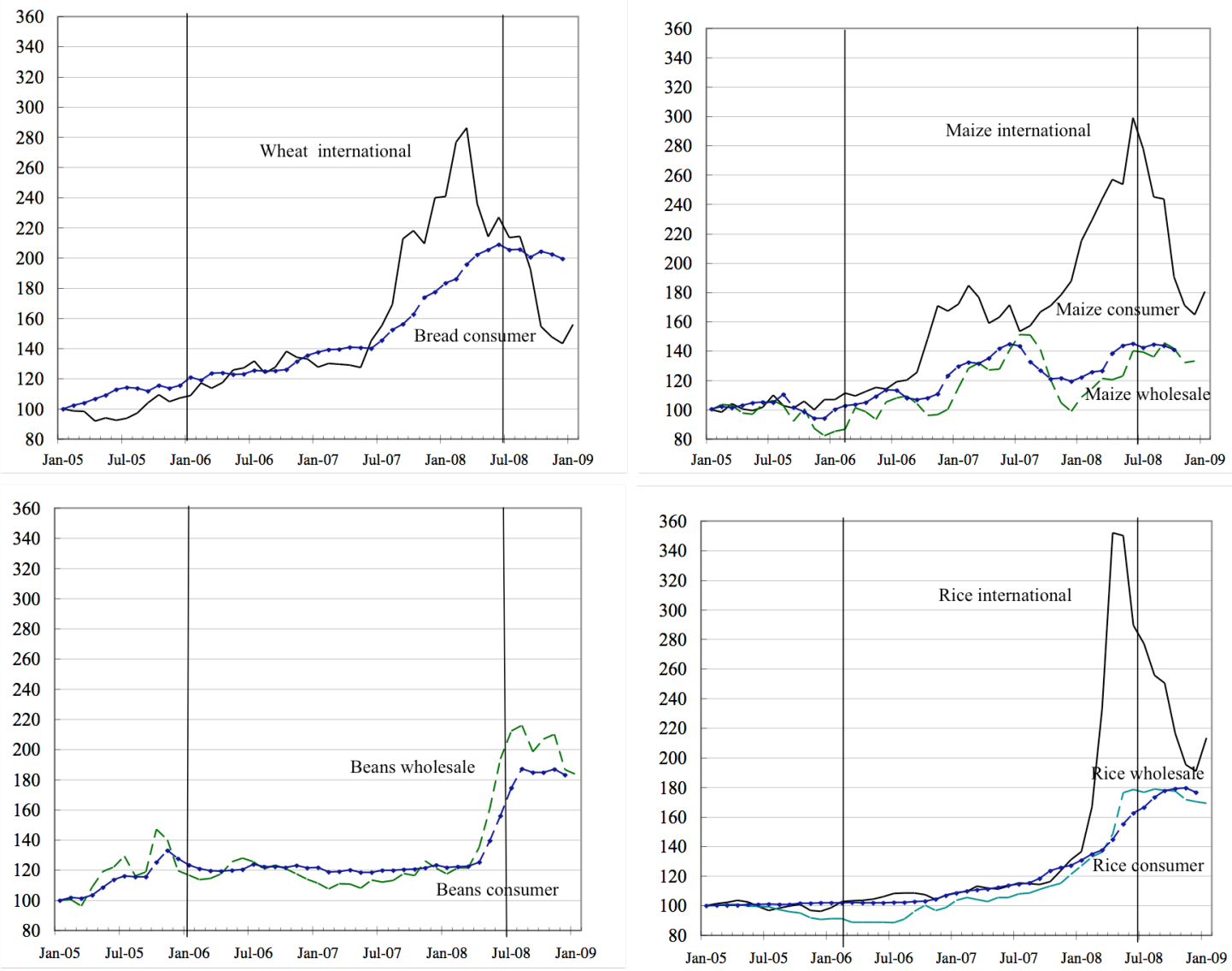

Sources: International commodity prices: IMF, IFS, http://www.imf.org/external/np/res/commod/index.asp.

Consumer prices: http://www.ine.gob.gt/index.php/economia;

Wholesale prices in central market of Guatemala city: Sistema de Información de Mercados, UPIE/MAGA. 
Figure 2. Food dependency in Guatemala

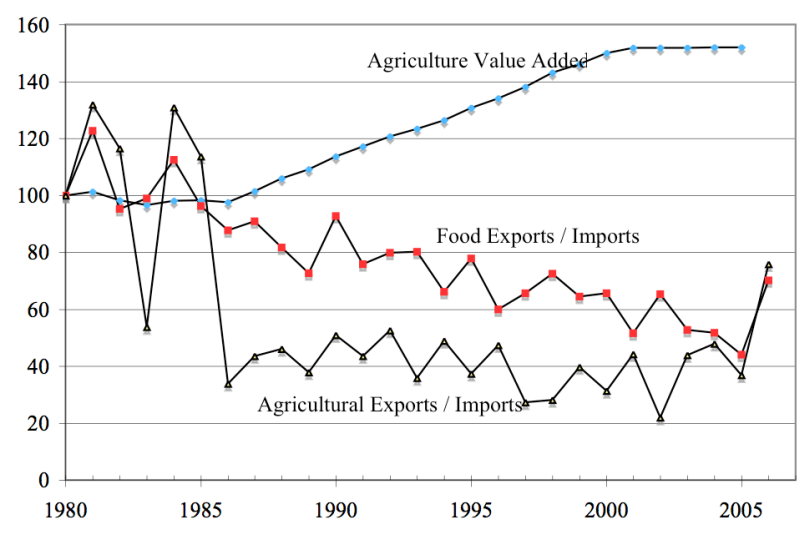

1980 value of Food exports/Food imports = 7.06. 1980 value of Agricultural exports/Agricultural imports = 7.39. Data source: World Bank, World Development Indicators

Figure 3. Density of consumption per capita by sector of residence and farm size

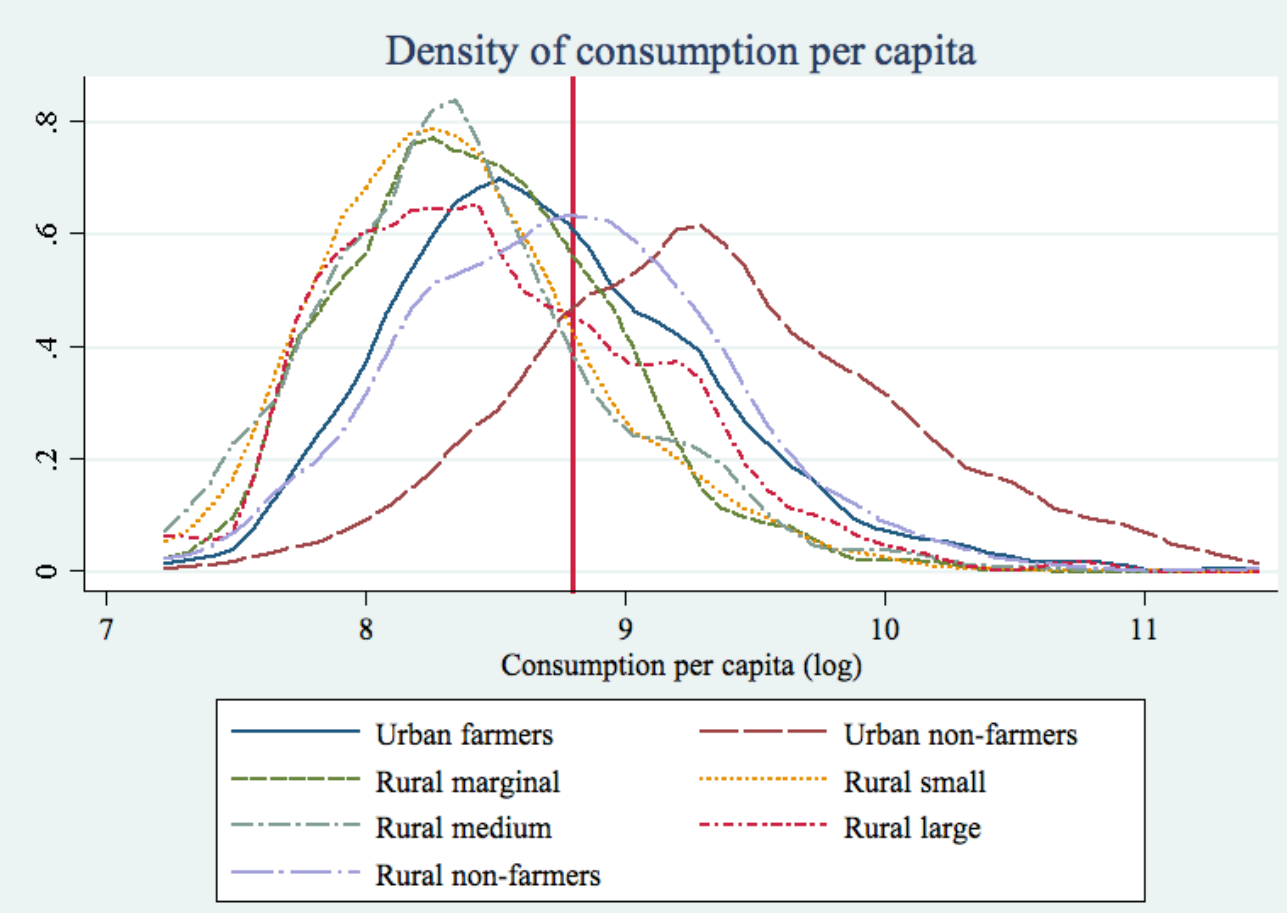


Table 1. Percentage changes in domestic and international prices and import dependency

\begin{tabular}{lccccc}
\hline & \multicolumn{2}{c}{$\begin{array}{c}\text { Annual growth rates January 2006 - July 2008 (\%) } \\
\text { Domestic WPI }\end{array}$} & $\begin{array}{c}\text { Consumer price } \\
\text { International price }\end{array}$ & $\begin{array}{c}\text { Average 2003-2005 } \\
\text { Import }\end{array}$ & $\begin{array}{c}\text { Share in basic grains } \\
\text { consumption }\end{array}$ \\
\hline Rice & 28.6 & 19.8 & 47.2 & 68.0 & 4.6 \\
Maize & 14.4 & 14.2 & 44.1 & 35.4 & 71.2 \\
Wheat & 10.7 & 26.8 (bread) & 42.9 & 98.4 & 19.9 \\
Beans & 5.7 & & 8.8 & 4.2 \\
Soybeans & & 54.4 & 18.1 & \\
Edible oil & & & & \\
CPI & & & & & \\
\hline
\end{tabular}

International commodity prices: IMF, IFS, http://www.imf.org/external/np/res/commod/index.asp

Consumer prices: http://www.ine.gob.gt/index.php/economia; Wholesale prices in central market of Guatemala city: Sistema de Información de Mercados, UPIE/MAGA.

Import dependency and consumption (defined as production + imports - exports) from FAOSTAT, FAO Statistics Division, 2009.

Table 2. Share of household types and poverty rates

\begin{tabular}{lcccccccc}
\hline \multirow{2}{*}{ Household categories } & \multicolumn{2}{c}{ Urban } & $\begin{array}{c}\text { Rural } \\
\text { Marginal } \\
\text { farmer }\end{array}$ & $\begin{array}{c}\text { Small } \\
\text { farmer }\end{array}$ & $\begin{array}{c}\text { Medium } \\
\text { farmer }\end{array}$ & $\begin{array}{c}\text { Large } \\
\text { farmer }\end{array}$ & Non-farmer & Total \\
\hline Share of population (\%) & 9.3 & 38.9 & 8.1 & 17.9 & 6.7 & 3.7 & 15.5 & 100 \\
Poverty rate (\%) & 59.1 & 23.1 & 76.2 & 80.9 & 79.5 & 69.1 & 52.0 & 51.0 \\
Share of the poor (\%) & 10.7 & 17.6 & 12.0 & 28.3 & 10.5 & 5.1 & 15.8 & 100 \\
\hline
\end{tabular}

Note: Marginal farmers are households with less than 0.5 manzanas of land in cultivation, small farmers witl between 0.5 manzanas and 2 manzanas, medium farmers with between 2 and 4 manzanas, and large farmers witl more than 4 manzanas. 1 manzana $=1.43$ ha. The poverty line used here is the general poverty line in 2006 equal to Q6,574 per capita per year (1 Quetzal $=0.13745$ US Dollar in 2006)

Source: Guatemala Household Survey, ENCOVI 2006 
Table 3. Structure of consumption and production, by sector of residence and farm size

\begin{tabular}{|c|c|c|c|c|c|c|c|c|}
\hline \multirow[b]{2}{*}{ Household categories } & \multicolumn{2}{|c|}{ Urban } & \multicolumn{5}{|c|}{ Rural } & \multirow[t]{2}{*}{ All } \\
\hline & Farmer & Non-farmer & $\begin{array}{l}\text { Marginal } \\
\text { farmer }\end{array}$ & $\begin{array}{l}\text { Small } \\
\text { farmer }\end{array}$ & $\begin{array}{c}\text { Medium } \\
\text { farmer }\end{array}$ & $\begin{array}{l}\text { Large } \\
\text { farmer }\end{array}$ & Non-farmer & \\
\hline Consumption per capita (Qz) & 7576.6 & 15097.4 & 5285.3 & 5013.0 & 5262.8 & 6072.4 & 7916.7 & 9697.6 \\
\hline \multicolumn{9}{|c|}{ Staple consumption (as \% of total expenditures) } \\
\hline Staples & 12.8 & 7.4 & 15.3 & 20.4 & 20.4 & 18.4 & 11.0 & 11.2 \\
\hline Maize & 7.2 & 2.5 & 9.0 & 13.9 & 14.2 & 12.1 & 4.8 & 5.7 \\
\hline Wheat & 3.0 & 3.3 & 2.8 & 2.7 & 2.5 & 2.6 & 3.5 & 3.1 \\
\hline Beans & 1.3 & 0.7 & 1.8 & 2.2 & 2.2 & 2.2 & 1.3 & 1.2 \\
\hline Rice & 0.6 & 0.4 & 0.8 & 0.8 & 0.7 & 0.7 & 0.6 & 0.5 \\
\hline Oil & 0.7 & 0.6 & 0.8 & 0.8 & 0.8 & 0.8 & 0.8 & 0.7 \\
\hline \multicolumn{9}{|c|}{ Cereal production (as \% of total expenditures) } \\
\hline Maize & 3.6 & & 2.6 & 6.1 & 9.5 & 15.4 & & 2.1 \\
\hline Beans & 0.9 & & 0.2 & 1.4 & 3.2 & 6.9 & & 0.6 \\
\hline Self-sufficiency in cereals (\%) & 48.9 & 6.4 & 41.2 & 67.1 & 76.3 & 74.4 & 12.5 & 36.6 \\
\hline Maize & 73.9 & 11.1 & 61.4 & 87.1 & 93.4 & 94.1 & 21.7 & 59.6 \\
\hline Beans & 28.3 & 3.7 & 14.2 & 42.0 & 65.1 & 67.8 & 6.6 & 25.1 \\
\hline Wheat & 6.0 & 3.6 & 4.3 & 2.7 & 10.4 & 6.5 & 3.5 & 4.1 \\
\hline Rice & 7.5 & 2.9 & 6.5 & 7.0 & 8.9 & 6.7 & 5.9 & 5.4 \\
\hline \multicolumn{9}{|c|}{ Share of production directly used by household (as \% of total expenditures) } \\
\hline Maize & 73.6 & & 94.1 & 82.7 & 65.3 & 38.0 & & 68.1 \\
\hline Beans & 57.6 & & 91.4 & 70.7 & 55.9 & 33.0 & & 53.0 \\
\hline Land (manzanas) & 1.3 & 0.0 & 0.3 & 1.2 & 2.9 & 7.4 & 0.0 & 0.8 \\
\hline
\end{tabular}


Table 4. Adjustment of the poverty line to account for price changes

Domestic prices International prices

\section{Consumption and production structure of marginal poor}

Annual consumption per capita $(\mathrm{Qz})$

6568.8

Official poverty line

6573.9

Staple consumption (\% of consumption)

14.9

Share of maize

Share of wheat

27.8

Share of households that cultivate land

45.3

Staple production (\% of consumption)

3.4

Share of maize

71.3

Share of beans

27.1

\section{Simulated effect of price changes on welfare of marginal poor}

Change in price of staple consumption

Change in per capita cost of consumption (Qz)

8.5
82.9

40.1

Change in per capita cost of consumption (in percent)

Change in price of staple production

$\begin{array}{ll}4.8 & 32.2\end{array}$

Change in per capita agricultural income $(\mathrm{Qz})$

All values have been adjusted by the spatial price deflator. Sample of households with consumption per capita within $5 \%$ of the poverty line.

Domestic prices: Simulation are of average annual percent changes of prices from January 2006 to July 2008, relative to CPI, i.e., for producer prices: $18.6 \%$ (rice), $5.6 \%$ (maize), and $2.1 \%$ (beans); and for consumer prices: $10.5 \%$ (rice), $5.3 \%$ (maize), $-2.5 \%$ (beans), $17 \%$ (bread), and $13.9 \%$ (edible oil). International prices: $47.2 \%$ (rice), $44.1 \%$ (maize), $42.9 \%$ (wheat), and $54.4 \%$ (soyabean/edible oil) for producer and consumer prices.

Source: ENCOVI 2006. 
Table 5. Simulated effects of staple food price changes on poverty, by sector of residence and farm size

\begin{tabular}{|c|c|c|c|c|c|c|c|c|}
\hline \multirow[b]{2}{*}{ Household categories } & \multicolumn{2}{|c|}{ Urban } & \multicolumn{5}{|c|}{ Rural } & \multirow[t]{2}{*}{ All } \\
\hline & Farmer & Non-farmer & $\begin{array}{c}\text { Marginal } \\
\text { farmer }\end{array}$ & $\begin{array}{l}\text { Small } \\
\text { farmer }\end{array}$ & $\begin{array}{l}\text { Medium } \\
\text { farmer }\end{array}$ & $\begin{array}{l}\text { Large } \\
\text { farmer }\end{array}$ & Non-farmer & \\
\hline \multicolumn{9}{|l|}{ Base values before price changes } \\
\hline Consumption per capita $(\mathrm{Qz})$ & 7577 & 15097 & 5285 & 5013 & 5263 & 6072 & 7917 & 9698 \\
\hline Poverty rate $(\%)$ & 59.1 & 23.1 & 76.2 & 80.9 & 79.5 & 69.1 & 52.0 & 51.0 \\
\hline \multicolumn{9}{|c|}{ Simulated effect of domestic price changes on poverty } \\
\hline Change in poverty line $(\mathrm{Qz})$ & 82.9 & 82.9 & 82.9 & 82.9 & 82.9 & 82.9 & 82.9 & 82.9 \\
\hline Change in poverty line (in percent) & 1.3 & 1.3 & 1.3 & 1.3 & 1.3 & 1.3 & 1.3 & 1.3 \\
\hline Poverty rate (no income effect) & 59.9 & 23.5 & 77.1 & 81.9 & 79.9 & 70.1 & 52.8 & 51.7 \\
\hline Change in per capita ag. income (Qz) & 17.9 & 0.0 & 8.3 & 19.2 & 32.5 & 67.1 & 0.0 & 10.4 \\
\hline Change in per capita ag. income (in percent) & 0.2 & 0.0 & 0.2 & 0.4 & 0.6 & 1.1 & 0.0 & 0.1 \\
\hline Poverty rate (including income effect) & 59.8 & 23.5 & 77.1 & 81.6 & 79.6 & 69.6 & 52.8 & 51.6 \\
\hline \multicolumn{9}{|c|}{ Simulated effect of international price changes on poverty } \\
\hline Change in poverty line $(\mathrm{Qz})$ & 394.8 & 394.8 & 394.8 & 394.8 & 394.8 & 394.8 & 394.8 & 394.8 \\
\hline Change in poverty line (in percent) & 6.0 & 6.0 & 6.0 & 6.0 & 6.0 & 6.0 & 6.0 & 6.0 \\
\hline Poverty rate (no income effect) & 62.6 & 25.8 & 79.4 & 83.8 & 81.7 & 72.4 & 56.3 & 54.1 \\
\hline Change in per cap. ag. income $(\mathrm{Qz})$ & 129.6 & 0.0 & 63.2 & 138.2 & 223.4 & 425.7 & 0.0 & 72.7 \\
\hline Change in per capita ag. income (in percent) & 1.7 & 0.0 & 1.2 & 2.8 & 4.2 & 7.0 & 0.0 & 0.7 \\
\hline Poverty rate (including income effect) & 61.8 & 25.8 & 78.8 & 82.8 & 79.9 & 70.1 & 56.3 & 53.6 \\
\hline
\end{tabular}

All values have been adjusted by the spatial price deflator.

Domestic prices: Simulation are of average annual percent changes of prices from January 2006 to July 2008, relative to CPI, i.e., for producer prices: $18.6 \%$ (rice), $5.6 \%$ (maize), and 2.1\% (beans); and for consumer prices: $10.5 \%$ (rice), $5.3 \%$ (maize), $-2.5 \%$ (beans), $17 \%$ (bread), and $13.9 \%$ (edible oil).

International prices: $47.2 \%$ (rice), $44.1 \%$ (maize), $42.9 \%$ (wheat), and $54.4 \%$ (soyabean/edible oil) for producer and consumer prices. Source: ENCOVI 2006. 
Table 6. Welfare effects of staple food price changes, by sector of residence and farm size: domestic price simulation

\begin{tabular}{|c|c|c|c|c|c|c|c|}
\hline \multirow[b]{2}{*}{ Household categories } & \multicolumn{2}{|c|}{ Urban } & \multicolumn{5}{|c|}{ Rural } \\
\hline & Farmer & Non-farmer & $\begin{array}{c}\text { Marginal } \\
\text { farmer }\end{array}$ & $\begin{array}{l}\text { Small } \\
\text { farmer }\end{array}$ & $\begin{array}{c}\text { Medium } \\
\text { farmer }\end{array}$ & $\begin{array}{l}\text { Large } \\
\text { farmer }\end{array}$ & Non-farmer \\
\hline \multicolumn{8}{|c|}{ Household purchases and sales (as \% of total expenditures) } \\
\hline \multicolumn{8}{|c|}{ Household food purchases } \\
\hline Rice & 0.5 & 0.4 & 0.8 & 0.7 & 0.7 & 0.7 & 0.6 \\
\hline Wheat & 2.8 & 3.1 & 2.7 & 2.6 & 2.3 & 2.4 & 3.4 \\
\hline Maize & 1.9 & 2.3 & 3.5 & 1.8 & 0.9 & 0.7 & 3.7 \\
\hline Beans & 1.0 & 0.6 & 1.6 & 1.3 & 0.8 & 0.7 & 1.3 \\
\hline Edible oils & 0.6 & 0.6 & 0.7 & 0.8 & 0.7 & 0.8 & 0.8 \\
\hline \multicolumn{8}{|l|}{ Value of food product sales } \\
\hline Rice & 0.0 & 0.0 & 0.0 & 0.0 & 0.0 & 0.6 & 0.0 \\
\hline Beans & 0.4 & 0.0 & 0.0 & 0.4 & 1.4 & 4.6 & 0.0 \\
\hline Maize & 1.0 & 0.0 & 0.2 & 1.1 & 3.3 & 9.6 & 0.0 \\
\hline \multicolumn{8}{|l|}{ Net buyers ( $\%$ of population) } \\
\hline Rice & 87.0 & 89.5 & 88.9 & 91.0 & 86.3 & 89.8 & 91.1 \\
\hline Wheat & 95.6 & 97.4 & 95.3 & 97.2 & 96.7 & 97.6 & 97.3 \\
\hline Maize & 62.8 & 95.4 & 79.9 & 45.9 & 27.6 & 15.2 & 93.1 \\
\hline Beans & 74.9 & 89.6 & 84.8 & 66.9 & 43.6 & 35.1 & 91.4 \\
\hline \multicolumn{8}{|c|}{ Net welfare gains (as \% of total expenditures) } \\
\hline From rice price & -0.1 & 0.0 & -0.1 & -0.1 & -0.1 & 0.0 & -0.1 \\
\hline From wheat price & -0.5 & -0.5 & -0.5 & -0.4 & -0.4 & -0.4 & -0.6 \\
\hline From maize price & 0.0 & -0.1 & -0.2 & 0.0 & 0.1 & 0.5 & -0.2 \\
\hline From beans price & 0.0 & 0.0 & 0.0 & 0.0 & 0.0 & 0.1 & 0.0 \\
\hline From oil price & -0.1 & -0.1 & -0.1 & -0.1 & -0.1 & -0.1 & -0.1 \\
\hline Overall gain & -0.6 & -0.8 & -0.8 & -0.6 & -0.4 & 0.1 & -0.9 \\
\hline Average loss for losers & 0.7 & 0.8 & 0.8 & 0.7 & 0.6 & 0.5 & 0.9 \\
\hline Average gain for gainers & 0.4 & 0.0 & 0.1 & 0.4 & 0.4 & 1.1 & 0.0 \\
\hline Net losers ( $\%$ of population) & 94.6 & 98.5 & 98.7 & 95.3 & 80.1 & 58.3 & 98.7 \\
\hline
\end{tabular}

All values have been adjusted by the spatial price deflator.

Domestic prices: Simulation are of average annual percent changes of prices from January 2006 to July 2008, relative to CPI, i.e., for producer prices: $18.6 \%$ (rice), $5.6 \%$ (maize), and $2.1 \%$ (beans); and for consumer prices: $10.5 \%$ (rice), $5.3 \%$ (maize), $-2.5 \%$ (beans), $17 \%$ (bread), and $13.9 \%$ (edible oil).

Source: ENCOVI 2006. 
Table 7. Welfare effects of staple food price changes, by sector of residence and poverty status: domestic price simulation

\begin{tabular}{|c|c|c|c|c|c|}
\hline & All & $\begin{array}{c}\text { Rural } \\
\text { non-poor }\end{array}$ & $\begin{array}{c}\text { Rural } \\
\text { poor }\end{array}$ & $\begin{array}{c}\text { Urban } \\
\text { non-poor }\end{array}$ & $\begin{array}{c}\text { Urban } \\
\text { poor }\end{array}$ \\
\hline \multicolumn{6}{|c|}{ Household purchases and sales (as \% of total expenditures) } \\
\hline \multicolumn{6}{|c|}{ Household food purchases } \\
\hline Rice & 0.5 & 0.5 & 0.8 & 0.3 & 0.8 \\
\hline Wheat & 3.0 & 3.0 & 2.7 & 2.9 & 4.0 \\
\hline Maize & 2.3 & 1.9 & 3.0 & 1.8 & 4.3 \\
\hline Beans & 0.9 & 0.8 & 1.6 & 0.5 & 1.7 \\
\hline Edible oils & 0.6 & 0.6 & 0.9 & 0.5 & 0.9 \\
\hline \multicolumn{6}{|l|}{ Value of food product sales } \\
\hline Rice & 0.0 & 0.0 & 0.1 & 0.0 & 0.0 \\
\hline Beans & 0.3 & 0.6 & 0.7 & 0.0 & 0.1 \\
\hline Maize & 0.7 & 1.2 & 1.8 & 0.1 & 0.3 \\
\hline \multicolumn{6}{|l|}{ Net buyers ( $\%$ of population) } \\
\hline Rice & 89.5 & 88.9 & 90.5 & 87.9 & 91.6 \\
\hline Wheat & 97.0 & 96.5 & 97.1 & 97.2 & 96.8 \\
\hline Maize & 74.4 & 69.1 & 57.2 & 92.3 & 81.7 \\
\hline Beans & 79.0 & 74.7 & 70.4 & 85.8 & 89.0 \\
\hline \multicolumn{6}{|c|}{ Net welfare gains (as \% of total expenditures) } \\
\hline From rice price & 0.0 & 0.0 & -0.1 & 0.0 & -0.1 \\
\hline From wheat price & -0.5 & -0.5 & -0.5 & -0.5 & -0.7 \\
\hline From maize price & -0.1 & 0.0 & -0.1 & -0.1 & -0.2 \\
\hline From beans price & 0.0 & 0.0 & 0.1 & 0.0 & 0.0 \\
\hline From oil price & -0.1 & -0.1 & -0.1 & -0.1 & -0.1 \\
\hline Overall gain & -0.7 & -0.6 & -0.7 & -0.7 & -1.1 \\
\hline Average loss for losers & 0.8 & 0.7 & 0.8 & 0.7 & 1.1 \\
\hline Average gain for gainers & 0.5 & 0.4 & 0.8 & 0.1 & 0.2 \\
\hline Net losers ( $\%$ of population) & 94.9 & 92.3 & 92.2 & 98.0 & 97.1 \\
\hline
\end{tabular}

All values have been adjusted by the spatial price deflator.

Domestic prices: Simulation are of average annual percent changes of prices from January 2006 to July 2008, relative to CPI, i.e., for producer prices: $18.6 \%$ (rice), $5.6 \%$ (maize), and $2.1 \%$ (beans); and for consumer prices: $10.5 \%$ (rice), $5.3 \%$ (maize), $-2.5 \%$ (beans), 17\% (bread), and 13.9\% (edible oil).

Source: ENCOVI 2006. 
Table 8. Welfare effects of staple food price changes, by sector of residence and farm size: international price simulation

\begin{tabular}{|c|c|c|c|c|c|c|c|}
\hline \multirow{2}{*}{ Household categories } & \multicolumn{2}{|c|}{ Urban } & \multicolumn{5}{|c|}{ Rural } \\
\hline & Farmer & Non-farmer & $\begin{array}{c}\text { Marginal } \\
\text { farmer }\end{array}$ & $\begin{array}{l}\text { Small } \\
\text { farmer }\end{array}$ & $\begin{array}{l}\text { Medium } \\
\text { farmer }\end{array}$ & $\begin{array}{l}\text { Large } \\
\text { farmer }\end{array}$ & Non-farmer \\
\hline \multicolumn{8}{|c|}{ Net welfare gains (as \% of total expenditures) } \\
\hline From rice price & -0.3 & -0.2 & -0.4 & -0.3 & -0.3 & 0.0 & -0.3 \\
\hline From wheat price & -1.2 & -1.3 & -1.2 & -1.1 & -1.0 & -1.0 & -1.5 \\
\hline From maize price & -0.4 & -1.0 & -1.5 & -0.3 & 1.0 & 3.9 & -1.6 \\
\hline From beans price & 0.0 & 0.0 & 0.0 & 0.0 & 0.0 & 0.0 & 0.0 \\
\hline From oil price & -0.3 & -0.3 & -0.4 & -0.4 & -0.4 & -0.4 & -0.4 \\
\hline Overall gain & -2.2 & -2.8 & -3.4 & -2.2 & -0.6 & 2.4 & -3.8 \\
\hline Average loss for losers & 2.6 & 2.9 & 3.5 & 2.6 & 2.1 & 2.3 & 3.8 \\
\hline Average gain for gainers & 2.7 & 0.0 & 0.5 & 2.4 & 3.0 & 5.9 & 0.0 \\
\hline Net losers ( $\%$ of population) & 91.4 & 98.5 & 98.2 & 91.5 & 71.2 & 46.5 & 98.7 \\
\hline
\end{tabular}

All values have been adjusted by the spatial price deflator.

Simulation are for average annual percent changes of international prices from January 2006 to July 2008: 47.2\% (rice), $44.1 \%$ (maize), $42.9 \%$ (wheat), and $54.4 \%$ (soyabeans/edible oils) for producer and consumer prices.

Source: ENCOVI 2006.

Table 9. Welfare effects of staple food price changes, by sector of residence and poverty status: international price simulation

\begin{tabular}{lccccc}
\hline & All & $\begin{array}{c}\text { Rural } \\
\text { non-poor }\end{array}$ & $\begin{array}{c}\text { Rural } \\
\text { poor }\end{array}$ & $\begin{array}{c}\text { Urban } \\
\text { non-poor }\end{array}$ & $\begin{array}{c}\text { Urban } \\
\text { poor }\end{array}$ \\
\hline Net welfare gains (as \% of total expenditures) & & & & \\
From rice price & -0.2 & -0.2 & -0.4 & -0.2 & -0.4 \\
From wheat price & -1.3 & -1.3 & -1.2 & -1.3 & -1.7 \\
From maize price & -0.7 & -0.3 & -0.5 & -0.8 & -1.8 \\
From beans price & 0.0 & 0.0 & 0.0 & 0.0 & 0.0 \\
From oil price & -0.3 & -0.3 & -0.5 & -0.3 & -0.5 \\
Overall gain & -2.6 & -2.1 & -2.6 & -2.5 & -4.3 \\
Average loss for losers & 3.0 & 2.8 & 3.5 & 2.5 & 4.6 \\
Average gain for gainers & 3.2 & 2.9 & 4.8 & 1.0 & 1.8 \\
Net losers (\% of population) & 92.8 & 89.3 & 88.6 & 97.7 & 95.9 \\
\end{tabular}

All values have been adjusted by the spatial price deflator.

Simulation are for average annual percent changes of international prices from January 2006 to July 2008: 47.2\% (rice), $44.1 \%$ (maize), $42.9 \%$ (wheat), and 54.4\% (soyabeans/edible oils) for producer and consumer prices.

Source: ENCOVI 2006. 
Table 10. Medium term welfare effects of staple food price changes, with supply and demand responses, by residence and farm size

\begin{tabular}{|c|c|c|c|c|c|c|c|}
\hline \multirow[b]{2}{*}{ Household categories } & \multicolumn{2}{|c|}{ Urban } & \multicolumn{5}{|c|}{ Rural } \\
\hline & Farmer & Non-farmer & $\begin{array}{c}\text { Marginal } \\
\text { farmer }\end{array}$ & $\begin{array}{c}\text { Small } \\
\text { farmer }\end{array}$ & $\begin{array}{l}\text { Medium } \\
\text { farmer }\end{array}$ & $\begin{array}{l}\text { Large } \\
\text { farmer }\end{array}$ & Non-farmer \\
\hline \multicolumn{8}{|l|}{ Net welfare gains (as \% of total expenditures) } \\
\hline Static welfare gains (from Table 10) & -2.2 & -2.8 & -3.4 & -2.2 & -0.6 & 2.4 & -3.8 \\
\hline Due to consumption and supply responses & 0.4 & 0.2 & 0.4 & 0.7 & 0.8 & 0.9 & 0.3 \\
\hline Total welfare gain & -1.8 & -2.6 & -3.0 & -1.5 & 0.1 & 3.4 & -3.5 \\
\hline Net losers ( $\%$ of population) & 87.8 & 98.5 & 95.3 & 80.7 & 58.4 & 38.0 & 98.0 \\
\hline \multicolumn{8}{|c|}{ All values have been adjusted by the spatial price deflator. } \\
\hline \multicolumn{8}{|c|}{$\begin{array}{l}\text { Simulation are for average annual percent changes of international prices from January } 2006 \text { to July } 2008: 47.2 \% \text { (rice), } 44.1 \% \text { (maize) } \\
42.9 \% \text { (wheat), and } 54.4 \% \text { (soyabeans/edible oils) for producer and consumer prices. }\end{array}$} \\
\hline
\end{tabular}

Table 11. Medium term welfare effects of staple food price changes, with supply and demand responses, by residence and poverty status

\begin{tabular}{lccccc}
\hline & All & $\begin{array}{c}\text { Rural } \\
\text { non-poor }\end{array}$ & $\begin{array}{c}\text { Rural } \\
\text { poor }\end{array}$ & $\begin{array}{c}\text { Urban } \\
\text { non-poor }\end{array}$ & $\begin{array}{c}\text { Urban } \\
\text { poor }\end{array}$ \\
\hline Net welfare gains (as \% of total expenditures) & & & & & \\
$\quad$ Static welfare gains (from Table 9) & -2.6 & -2.1 & -2.6 & -2.5 & -4.3 \\
$\quad$ Due to consumption and supply responses & 0.3 & 0.3 & 0.7 & 0.2 & 0.4 \\
$\quad$ Total welfare gain & -2.3 & -1.8 & -1.9 & -2.3 & -3.9 \\
Net losers (\% of population) & 89.0 & 86.4 & 80.4 & 97.3 & 94.2 \\
& & & & & \\
\hline
\end{tabular}

All values have been adjusted by the spatial price deflator.

Simulation are for average annual percent changes of international prices from January 2006 to July 2008: $47.2 \%$ (rice), $44.1 \%$ (maize), $42.9 \%$ (wheat), and 54.4\% (soyabeans/edible oils) for producer and consumer prices.

Supply elasticities assumed equal to 0.3 and demand elasticities assumed equal to -0.3 for rice, wheat, and maize. Source: ENCOVI 2006. 
Table 12. Share of farmers among poor losers from the rise in staple food prices

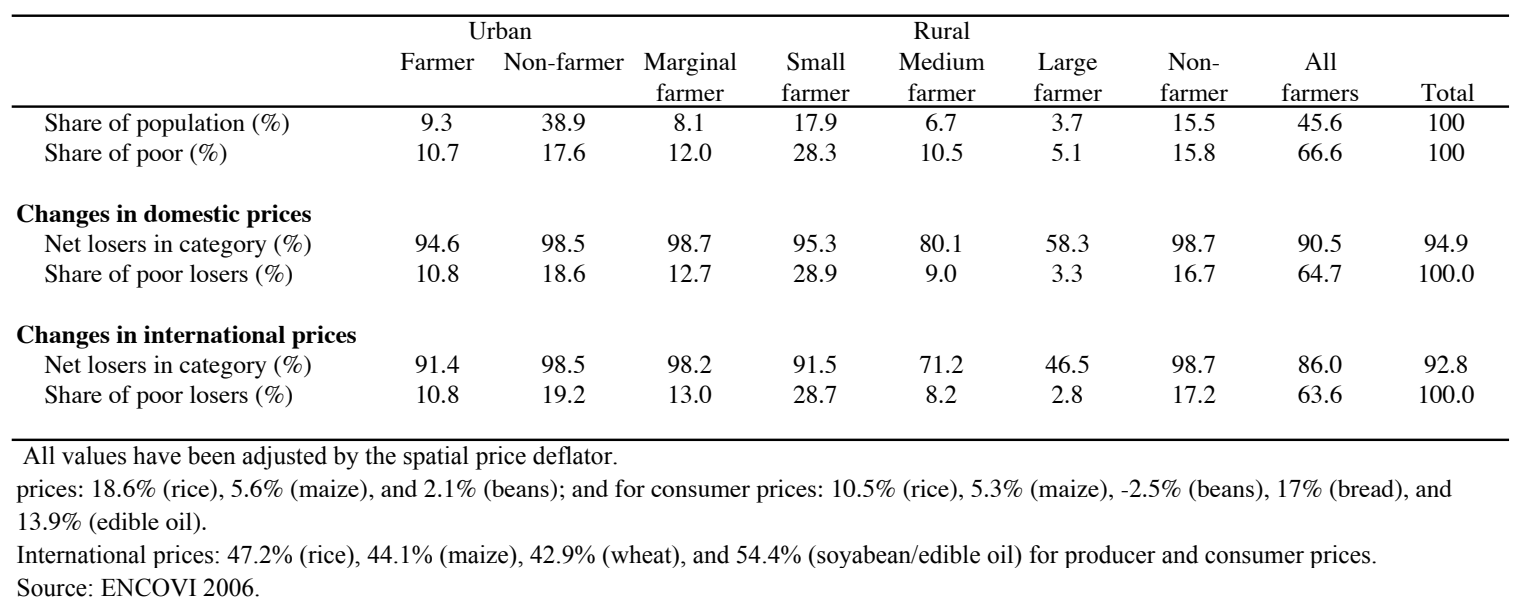

